\title{
COPING STRATEGY AND CHILDREN CHARACTERISTIC TO PARENTAL ACCEPTANCE IN PARENTS OF CHILDREN WITH LEUKEMIA USING TRANSACTIONAL THEORY APPROACH
}

\author{
(Coping Strategy dan Karakteristik Anak terhadap Parental Acceptance Orang Tua yang \\ Mempunyai Anak Leukemia dengan Pendekatan Transactional Theory)
}

\author{
Iqlima Dwi Kurnia, Yuni Sufyanti Arief, Kristiawati \\ Nursing Faculty of Universitas Airlangga Kampus C Mulyorejo Surabaya. \\ E-mail: iqlimaners@gmail.com
}

\begin{abstract}
ABSTRAK
Pendahuluan. Leukemia merupakan kanker yang paling banyak terjadi pada anak 33\% dari keseluruhan jumlah kanker pada anak. Tujuan penelitian ini untuk mengetahui hubungan coping strategy dan karakteristik anak terhadap parental acceptance orang tua yang mempunyai anak leukemia. Metode. Desain dalam penelitian ini adalah cross-sectional. Populasi dalam penelitian ini adalah orang tua (ibu) yang mempunyai anak dengan leukemia di RSUD Dr. Soetomo Surabaya, dengan teknik consecutive sampling. Jumlah sampel sebanyak 23 ibu. Pengukuran Coping strategy dinilai dengan menggunakan kuesioner modifikasi dari Lazarus \& Folkman Appraisal stress and Coping strategy in Transactional Theory, pengukuran parental acceptance menggunakan kuesioner. Data kemudian diolah dan dianalisa menggunakan uji korelasi pearson dan spearman rank, hipotesis alternatif diterima jika $\mathrm{p}<0,05$. Hasil. Hasil penelitian menunjukkan hasil yang signifikan antara hubungan coping strategy dengan parental acceptance $(\mathrm{p}=0,000)$. Untuk hubungan karakteristik anak dengan parental acceptance, variabel tahapan pengobatan $(\mathrm{p}=0,000)$, klasifikasi penyakit $(0,004)$ dan lama sakit menunjukkan hasil signifikan $(\mathrm{p}=0,000)$, sedangkan variabel umur dan anak keberapa menunjukkan hasil yang tidak signifikan dengan parental acceptance. Diskusi. Parental acceptance yang baik hanya akan terjadi bila orang tua mau dan mampu mamahami keadaan diri sebagaimana adanya.
\end{abstract}

Kata kunci: Parental acceptance, anak dengan leukemia, primary appraisal, coping strategy

\begin{abstract}
Introduction. Leukemia is a kind of cancer that most occur in children $33 \%$ of the total number of childhood cancer. The purpose of this study was to determine the relationship of coping strategy and children characteristic to parental acceptance in parents of children with leukemia. Method. Design used in this study was cross-sectional. Population in this study was parents (mothers) of children with leukemia in Dr. Soetomo Hospitals Surabaya, with consecutive sampling technique. Total sample was 23 mothers. Coping strategy measurement was done using questionnaire modification from Lazarus \& Folkman Appraisal stress and coping strategy in Transactional Theory, parental acceptance was measured using questionnaire. Data that obtained then was processed and analyzed using spearman and pearson correlation, alternative hypothesis would be accepted if $p<0.05$. Result. The results of this study showed that the relationship between coping strategy with parental acceptance was significant $(p=0.000)$. For the relationship between children characteristics with parental acceptance, variable of phase of treatment, illness classification and duration of illness showed a significant result $(p=0.000)$, whereas variables of children age and children sequences showed insignificant results with parental acceptance. Discussion. Good parental acceptance will only happen if parents are willing and capable in understanding themselves.
\end{abstract}

Keywords: Parental acceptance, children leukemia, primary appraisal, coping strategy

\section{INTRODUCTION}

Leukemia is a malignant derived from genetic changes in one or more cells in the bone marrow. Normal cells growth will be depressed at the time of leukemic cells multiply and will produce clinical signs/symptoms (Suryati, 2010). Children who ill physically would be followed by psychic impaired in their parents. The first reaction in parents of children with leukemia after heard the diagnosis to their children were shocked, surprised, denying, parents deny what happened to their children. The sick condition in children, caused parents to stress, this relates with how parents treat children (James \& Ashwill, 2007). Parental acceptance is characterized by great attention and affection to children (Hurlock, 2000). According to Ismail (2008) characteristics 
of parental acceptance including: parents have self confidence, feel valuable, accept criticism, weaknesses and accept the children condition. All this time there was no model of parental acceptance in ward. The results of preliminary studies that have been conducted in the children hematology ward in RS Dr. Soetomo, obtained data that $50 \%$ parents of children with leukemia have negative parental acceptance, they said they could not accept the conditions that experienced by children.

Aziz (2005) stated that Leukemia or blood cancer is one type of cancer that often found in children, which is $25-30$ percent of all childhood cancer. Leukemia cases In Dr. Sardjito Hospital from 1992 until July 1998 was reported that leukemia in children was $48 \%$ of all cancer cases in childhood (Sutaryo, 2000). Research conducted by Mori (2004) showed that the problems faced by parents of children with cancer are physical and psychological fatigue such as anxiety and anger. Feelings of sadness and depression can also occur in parents of children with cancer (Keene, 2002). Parents also complained about the length of treatment that children should be undergoing and their physical condition which tends to decrease during treatment. In addition, the main problem was the high cost of treatment that burdening parents.

Stressors that faced by parents of children with leukemia will affect their selfacceptance to children condition, it will affect parents' role and ability in care and treatment their children. Therefore, it needs to know the factors that influence parental acceptance (Aziz, 2005). When individuals lack to accept self, it can lead to emotional disorders. Inability to accept self can lead to emotional difficulties such as anger and depression.

Parental acceptance in parents of children diagnosed with leukemia can be increased by maximizing factors that cause the stressor. There are several categories of sources of stress that contribute to the occurrence of stress in parents of children diagnosed with leukemia, including personal stressors and environmental stressors (Lazarus \& Folkman, 1991). According to Lazarus (1991) there are several coping strategy used by an individual while dealing with stress including confrontive coping, seeking social support, accepting responsibility, problem solving, positive reappraisal, distancing, self controlling, escape-avoidance.

Well self-acceptance will only occur when the individual concerned and able to understand their own situation as they are, not as they desired. Moreover, they should have realistic expectations, according to their ability. Thus, when an individual has a pleasant and rationale concept of the self, it could be said that individual could be fond and accept himself (Hurlock, 1985).

\section{METHOD}

Design used in this study was correlation study with cross sectional approach. The population in this study was parents (mothers) of children with leukemia in children hematology ward (Bona I) of Dr. Soetomo Hospital Surabaya with total sample was 30 . Sample in this study was determined based on inclusion and exclusion criteria. Sampling methods that was used in this study was non probability sampling with consecutive sampling. The independent variable in this study was coping strategy and children characteristics: age, children sequences, duration of illness, illness classification, and phase of treatment. The dependent variable in this study was Parental Acceptance. The instrument used in this study was a questionnaire. Measurement of coping strategy in this study was modification of the questionnaire Ways of Coping Strategy (Lazarus \& Folkman, 1988). 


\section{RESULT}

Table 1. The relationship of children characteristic with Parental acceptance

\begin{tabular}{|c|c|c|c|c|}
\hline \multirow{2}{*}{ Children Characteristic } & \multicolumn{3}{|c|}{ Parental Acceptance } & \multirow{2}{*}{$\begin{array}{c}\text { Total } \\
\%\end{array}$} \\
\hline & Positive & Negative & $\mathbf{N}$ & \\
\hline \multicolumn{5}{|l|}{ Children Age } \\
\hline 4-6 years & 3 & 4 & 7 & 30,43 \\
\hline 7-12 years & 5 & 11 & 16 & 69,57 \\
\hline \multicolumn{5}{|l|}{ Phase of Treatment } \\
\hline Induction & 2 & 7 & 9 & 39,13 \\
\hline Consolidation & 6 & 8 & 14 & 60,87 \\
\hline Remission & - & - & - & - \\
\hline \multicolumn{5}{|l|}{ Illness Duration } \\
\hline$<1$ month & 0 & 2 & 2 & 8,70 \\
\hline 1 month & 2 & 4 & 6 & 26,09 \\
\hline 2 months & 2 & 0 & 2 & 8,70 \\
\hline 3 months & 2 & 3 & 5 & 21,74 \\
\hline$>3$ months & 1 & 7 & 8 & 34,77 \\
\hline \multicolumn{5}{|l|}{ Children sequences } \\
\hline 1.1 & 0 & 5 & 5 & 21,74 \\
\hline 2.2 & 8 & 2 & 10 & 43,47 \\
\hline 3.3 & 0 & 8 & 8 & 34,78 \\
\hline \multicolumn{5}{|l|}{ Illness Classification } \\
\hline L1 & - & - & 1 & 4,34 \\
\hline L2 & 0 & 1 & 22 & 95,65 \\
\hline L3 & 7 & 15 & & \\
\hline \multicolumn{5}{|c|}{$\mathrm{P}=0,000$} \\
\hline
\end{tabular}

Table 2. Association of Coping Strategy to Parental Acceptance in Children Hematology Ward of Dr. Soetomo Hospital Surabaya 17 April- 19 May 2014

\begin{tabular}{lcccc}
\hline \multirow{2}{*}{ Coping Strategy } & \multicolumn{2}{c}{ Parental Acceptance } & \multicolumn{2}{c}{ Total } \\
\cline { 2 - 5 } & Positive & Negative & N & \% \\
\hline Problem Focused Coping & 9 & - & 9 & 39.13 \\
\hline Emotional Focused Coping & - & 14 & 14 & 60,87 \\
\hline & $\mathrm{P}=0.000$ & & & \\
\hline
\end{tabular}

\section{DISCUSSION}

Relationship between Coping Strategy with Parental Acceptance in Parents of Children with Leukemia

The analysis results showed significant relationship between coping strategy used parents when deal to problem with parental acceptance in parents of children with leukemia. Table 2 shows the result that majority respondent used emotional focused coping. Less than half of the respondents used distancing coping strategy, the second larger order is positive reappraisal and only one respondent that used self- controlling coping strategy and escape-avoidance. Almost all respondents have a negative parental acceptance. Respondents that used positive reappraisal coping strategy, all have positive parental acceptance, respondents and that used seeking social support coping strategy almost all respondents have a positive parental acceptance and only one respondent. The respondents who use an escape-avoidance coping strategy have a negative parental acceptance.

Coping strategies (coping) is a process in which individuals seek to deal with and control 
stressful situations as a result of the problem that faced by them with make cognitive and behavioral changes in order to gain a sense of security (Mu'tadin, 2002). According to Lazarus (1986) seeking social support is using effort to search sources of support information, social support and emotional support. This statement was reinforced by almost all respondents that chose to ask the doctors and nurses who care for their children, and respondents also ready to accept inputs to do things better. According to Lazarus \& Folkman (1986) distancing is the effort to relieve self, pay more attention to things that can create a positive view. Positive reappraisal is the effort to create positive things to focus on self and also concerning religiosity. Coping produce two purposes, first that individuals attempt to change the relationship between himself and the environment in order to produce a better impact, second that individuals usually seek to relieve, or eliminate the coping burden and emotional stress that they felt (Safaria, 2009). Parent's acceptance is a coping mechanism in which an individual accepts the reality of a stressful situation as efforts to deal with the situation and circumstances. Acceptance occurs in state where a problem is something that unavoidable and could not be changed. Acceptance is characterized by a positive attitude, acknowledgment or respect for individual values but include acknowledgment of their behavior (Chaplin, 2000). Sutikno (1993) states that acceptance is the basis for individuals to be able to accept the facts of life, all experience is good or bad.

Several different coping strategy used by parents showed that there was no correlation with parental acceptance, it could happen for several reasons including, parents' education, most of parents education was junior high school and as a housewife. Low education caused lack of information that received by parents (mothers), this lack of information cause ignorance of the disease, and parents difficult to accept their children conditions. Mother's role as housewives, parents also lack of knowledge, this was according to interviews with parents of children with leukemia who said they never read a book or browsing the internet, they just focus on housework. In addition, parents (mothers) that not working, psychologically more anxious than parents who work associated with finance condition. In this study, majority of respondents were financed by BPJS. However, parents still require extra costs for their children needs during hospitalization. From total fifteen parents that had negative parental acceptance, seven of them had unstable children condition.

Although parents have used seeking social support coping strategy where parents tried to find support information sources, social and emotional support, but this study results showed that several parents had negative parental acceptance, this often occurs in parents with two children and frightened if lost one of their children.

Coping strategy that used by parents when deals with a problem was affect parental acceptance, many factors that affect parental acceptance including beliefs, realistic expectations, how individuals view themselves, education and social support. Social support is a convenience, attention, reward, or assistance that received by individual from others (Ismail, 2008). Social support provided by the family could be emotional support, appraisal support, instrumental support and informational support. Patients were able to rely on other people if necessary and do not need encouragement exceed their durability or forced limitations or the inadequate. Parents were able to receive their condition because of their belief that children was entrusted of God that any children condition should be accepted. Essentially humans use a particular coping strategy to leave of an unpleasant situation

\section{Relationship between Children Characteristics (Age, Illness Duration, Children Sequences, Illness Type/ Classification, Phase of Treatment) with Parental Acceptance in Parents of Children with Leukemia}

Based on table 1 the age of the children, more than half children' age was in the range of 7-12 years and most of the parents have negative parental acceptance. The results 
showed that age did not affect the parental acceptance.

Children age in primary school according to Piaget's theory of cognitive development is at stage concrete operational. At this age, children start to show learning behavior. Age affects individual psychology, the older of age, better person level of maturity in dealing with various problems. However, the results of this study showed that the older children age or the younger children age with leukemia, the more difficult for parents to accept the fact/reality. It can be concluded that regardless of children age diagnosed with leukemia, parents would be difficult to accept the reality.

Primary school age children according to Piaget's theory of cognitive development were at concrete operational stage. In this age range children start to show learning behavior. Based on discussions, parents would more increasingly sad and hard to accept the condition of the children, when considering that children had to quit school because often come in and out to hospital. This was also due to when children grow older, they began to enter the higher education, began to like playing with peers, so that when a children got sick parents really feel lost the figure of children they desire and they expect to be a successor to the family. Some parents who had preschool-age children also feel the same when children was diagnosed with leukemia, parents feel upset, shocked, denying and feel guilty to themselves for illness that been suffered by their children.

Most of respondents' children had illness duration more than three months. In this study showed a significant result, there was a relationship between illness duration with parental acceptance, which means that the longer children were treated in hospital, the more parents felt stress and had negative parental acceptance. Most children who had duration of illness more than three months had parents with negative parental acceptance. Regarding to opinions that stated by James and Aswil (2007) that parents experience anxiety and stress when their children was hospitalized. The longer children being hospitalized, then the parents should provide extra costs and also spent considerable time in the hospital. Parents' self-acceptance is also associated with the experience of parents during their children illness and during hospitalization, possibility occur because parents are more anxious and stressed when children was hospitalized for treatment. The feeling that more anxious or stress experienced by the parents caused parents difficult to accept the fact that occur in children.

Children sequences showed insignificant results to parental acceptance in parents of children with leukemia. The birth order in the family or children sequences has an important role in shaping one's personality. Person's birth order has a direct relationship with his personality. The results showed that the majority of respondents' children were second order, and most respondents had positive parental acceptance. The sequence of children did not affect parental attitudes towards parental acceptance, it was based on the results of interviews with the parents that if one of the children being sick, they would remain sad and feel the same. Parents said they wanted all their children to grow up healthy and could be a successor to the family. All parents want their children to grow into a successful person and can encourage their parents.

Most of the respondents' children included in the L3 classification which means consists of homogeneous lymphoblast and can occur in both adults and children with a poor prognosis. Only one respondent child included in L2 classification and also had negative parental acceptance. Unfavorable prognostic factor in children with cancer including: aged $<2$ years or $>10$ years, initial leukocyte count more than 50/109, the mass presence in the mediastinum, L2 or L3 lymphoblast type, the presence of central nervous system diseases. The comparison of the number of respondents' children were not balanced between the L2 and L3 type, which in this study almost all respondents children suffering from leukemia type L3, so that researchers could not generalize if the only type of leukemia L3 caused parents to have a negative parental 
acceptance. The results showed that parents that have child with type L2 and L3 leukemia had the same negative parental acceptance. Based on the results of interviews with one of the parents of children with leukemia with L2 type, the parents said that they afraid of losing their child, the parents said that type L2 Leukemia has a poor prognosis of the L3, their children condition was different than other children in their ward.

The results of this study showed that the majority of respondents' children were at the consolidation phase of treatment and more than half of the parents had negative parental acceptance.

Consolidation therapy performed after induction therapy was completed and the child's condition is stable to continue the therapy, takes place on the eighth week to twelve weeks after diagnosis. During the treatment phase, the condition of each child will give different responses. If the child's condition decline and weakened, the parents will return to crisis conditions. This is consistent with the results of discussions with parents that said that they would felt sad and could not believe what happened when they saw the condition of children who drop or unstable. Every time children undergoing the treatment episodes either induction or consolidation phase, all episodes gave the side effects of treatment.

Each child would show different responses. After treatment if the children condition improves parents (mothers) would respond well and do not assume that the treatment that has been carried out as a threat or danger. However, if the children condition declined after treatment, then the parents will assume and perceive this as a threat and a danger, so parents (mothers) would return not accept the children condition. This is consistent with the opinions that expressed by some parents that said that when there was one children with who died, parents would return to feel sad to the illness that the children suffered. Conditions such these remind them, that one day the event will also bear on their children. Parents said that when in the hospital, they were always haunted by feelings of fear, anxiety and uncertainty. When at the beginning of hospital admission, the parents got explanation regarding to child's condition, treatment and prognosis of the illness of child. This made it difficult for parents accept the child's condition.

\section{CONCLUSION}

Children characteristics at variable: phase of treatment, the illness classification and illness duration influence parental acceptance, which means that the longer children treated at the hospital the more positive parental acceptance in parents. Parents whose children suffer from type L2 and L3 leukemia had negative parental acceptance. Most parents whose children are at the level of consolidation treatment have a negative parental acceptance.

\section{RECOMMENDATION}

This results of this study also showed that parental acceptance in parents of children with leukemia was affected by the illness classification, illness duration and phase of treatment. Good parental acceptance will only happen if parents are willing and capable in understanding themselves.

\section{REFERENCES}

Azis, M.F. (2005). Naskah Publikasi Strategi pengatasan Masalah pada Orang Tua Pasien Leukemia. Fakultas Psikologi Universitas Islam Indonesia: Yogyakarta.

Chaplin, J.P. (1999). Kamus Lengkap psikologi (Terjemahan dari Dr. Kartini Kartono), Jakarta: PT. Raja Grafindo Persada

Folkmas, F. (1986). Ways Of Coping Scales. http://www.mindgarden.com/. Diakses Pada Tanggal 8 Desember 2013. Jam 12.45 WIB

Hurlock, E.B. (1973). Adolecent Development. Tokyo: McGraw-Hill, Kogakusha, Ltd.

Hurlock, E.B. (1997). Psikologi Perkembangan Suatu Pendekatan Sepanjang Rentang Kehidupan. Ahli bahasa: Isti Widayanti dan Soedjarwo. Edisi kelima. Jakarta: Erlangga 
Hurlock, E.B. (2000). Perkembangan anak jilid II, Edisi keenam. Alih bahasa: dr. Med. Meitasari Tjandrasa. Jakarta: Erlangga

Ismail, A. (2008). Hubungan antara Dukungan sosial dengan penerimaan diri ibu dari anak Autis. Fakultas Psikologi Universitas Katolik Soegijapranata Semarang. Htttp: http://eprints.unika. ac.id/2058/1/04.40.0194_Amalia Ismail.pdf. Diakses tanggal $2 \overline{3}$ November 2013. Jam 10.43 WIB

James, S.R., \& Ashwill, J.W. (2007). Nursing care of children: Principle \& practice. Canada: Saunders Elsevier

Keene, N. (2002). Behavioral Changes of Parents.http://www.patientcenters.com/ leukemia/news.htm

Lazarus R.S, Folkman S. (1986). Stress, appraisal, and Coping. New York: Springer Publishing Company

Lazarus, RS, (1996). Psychlgical Stress and The Coping Process. New York: McGraw Hill

Lazarus \& Taylor, (1991). Emotion and adaptation. Londn: Oxford University Press

Lazarus, R.S., \& Folkman, S, (1987). Transactional theory and research on emotion and coping. European Journal of Personality, Vol. 1, hal. 141-170

Lazarus, RS \& Folkman S, (1988). Ways of Coping Questionnare. Consulting Psychlogist, Inc.
Mu'tadin. (2002). Strategi Coping. http://www. e-psikologi.com/remaja/zainun.htm. Diakses tanggal 17 November 2013. Jam 09.30 WIB

Mori, M.M. (2004). Multivariate Analysis of The Problems which Parents of Children with Malignant Disease Have. Journal of Pediatric Blood \& Cancer. SIOP abstracts. 43(4): 362-363.

Safaria, T. (2005). Autisme: Pemahaman baru untuk hidup bermakna bagi orang tua. Graha Ilmu Yogyakarta

Suryati, (2010). Hubungan Koping Orang Tua dan Karakteristi Anak dengan Pertumbuhan dan Perkembangan Anak Usia Battita dan Pra sekolah penderita leukemia Limfositik Akut di RSAB Harapan Kita Jakarta. Tesis. Fakultas Ilmu Keperawatan Program Pasca Sarjana Ilmu Keperawatan Kekhususan Keperawatan Anak. Depok Juli 2010. http://lontar.ui.ac.id/file?file=digital/ 20285747-T\%20Suryati.pdf. Diakses tanggal 2 Desember 2013. Jam 12.24 WIB

Sutaryo. (2000). The Protocol of Wijaya Kusuma Acute Lymphoblastic Leukemia of Childhood 2000. Yogyakarta: Sardjito General Hospital.

Sutikno, D.A. (1993). Persepsi tentang penerimaan orangtua, konsep diri, dan prestasi belajar pada remaja tunarungu. Skripsi (Tidak diterbitan) Fakultas Psikologi Universitas Indonesia. Depok. 